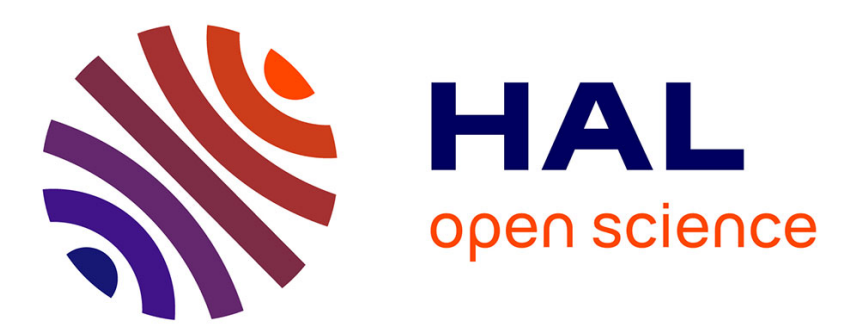

\title{
Coupling water and carbon cycle in the biosphere. / Couplage du cycle de l'eau et du carbone dans la biosphère
}

\author{
Nathalie De Noblet, Nicolas Viovy
}

\section{- To cite this version:}

Nathalie De Noblet, Nicolas Viovy. Coupling water and carbon cycle in the biosphere. / Couplage du cycle de l'eau et du carbone dans la biosphère. Sciences Géologiques Bulletin, 1997, 50 (1), pp.109 121. 10.3406/sgeol.1997.1948 . hal-03334042

\section{HAL Id: hal-03334042 \\ https://hal.science/hal-03334042}

Submitted on 3 Sep 2021

HAL is a multi-disciplinary open access archive for the deposit and dissemination of scientific research documents, whether they are published or not. The documents may come from teaching and research institutions in France or abroad, or from public or private research centers.
L'archive ouverte pluridisciplinaire HAL, est destinée au dépôt et à la diffusion de documents scientifiques de niveau recherche, publiés ou non, émanant des établissements d'enseignement et de recherche français ou étrangers, des laboratoires publics ou privés. 


\section{Coupling water and carbon cycle in the biosphere. / Couplage du} cycle de l'eau et du carbone dans la biosphère

Nicolas Viovy, Nathalie de Noblet

\section{Citer ce document / Cite this document :}

Viovy Nicolas, Noblet Nathalie de. Coupling water and carbon cycle in the biosphere. / Couplage du cycle de l'eau et du carbone dans la biosphère. In: Sciences Géologiques. Bulletin, tome 50, n¹-4, 1997. The global carbon cycle in the terrestrial biosphere. pp. 109-121;

doi : https://doi.org/10.3406/sgeol.1997.1948

https://www.persee.fr/doc/sgeol_0302-2692_1997_num_50_1_1948

Fichier pdf généré le 18/06/2018 


\begin{abstract}
Coupling the carbon and water cycles in the biosphere is of first importance for understanding both the carbon cycle and the role of the biosphere in the climate system. In this paper we present such coupling between a land surface scheme SECHIBA and biogeochemical processes (e.g. photosynthesis). Two approaches are proposed : (1) coupling SECHIBA with an existing biogeochemical model FBM, and (2) make a new model based on SECHIBA. This second way appears to be more promising. Hence coupling between SECHIBA and FBM that have not been designed for this purpose introduce large problem of instability.

The SECHIBA was modified to include parameterization of photosynthesis and a new parameterization of stomatal conductance that takes into account the effect of atmospheric $\mathrm{CO}_{2}$ on stomatal conductance. Validation with ground measurements gives satisfying results. Simulation with a doubled atmospheric $\mathrm{CO}_{2}$ shows little effect on transpiration when $\mathrm{CO}_{2}$ fertilization effect is important. But if this effect is limited for instance by nitrogen limitation, the decrease of transpiration becomes important.
\end{abstract}

\title{
Résumé
}

Couplage du cycle de l'eau et du carbone dans la biosphère

Le couplage entre cycle de carbone et cycle de l'eau dans la biosphère terrestre est très important pour comprendre son rôle dans le cycle du carbone et sur le système climatique. Cet article présente un tel couplage entre un schéma de surface (SECHIBA) et une paramétrisation de processus biogéochimiques (comme par exemple la photosynthèse). Deux approches sont proposées : (1) coupler SECHIBA avec un modèle existant (FBM) et (2) construire un nouveau modèle biogéochimique sur la base de SECHIBA. Cette deuxième approche semble plus prometteuse. En effet, le couplage entre deux modèles (SECHIBA et FBM) qui n'ont pas été conçus dans cette optique pose de gros problèmes d'instabilité.

SECHIBA a été modifié pour inclure une paramétrisation de la photosynthèse et de la conductance stomatique qui prenne en compte l'effet du $\mathrm{CO}_{2}$ atmosphérique sur cette dernière. La comparaison à des mesures de terrain donne des résultats satisfaisants. Une simulation en doublement de $\mathrm{CO}_{2}$ montre une influence faible sur le flux de transpiration lorsque l'effet de fertilisation est total. En revanche, la limitation de la transpiration devient nettement plus importante si l'on suppose que l'effet de fertilisation est limité par un manque d'azote par exemple. 


\title{
COUPLING WATER AND CARBON CYCLE IN THE BIOSPHERE
}

\author{
Nicolas VIOVY ${ }^{1}$ et Nathalie de NOBLET ${ }^{1}$
}

\begin{abstract}
Coupling the carbon and water cycles in the biosphere is of first importance for understanding both the carbon cycle and the role of the biosphere in the climate system. In this paper we present such coupling between a land surface scheme SECHIBA and biogeochemical processes (e.g. photosynthesis). Two approaches are proposed: (1) coupling SECHIBA with an existing biogeochemical model FBM, and (2) make a new model based on SECHIBA. This second way appears to be more promising. Hence coupling between SECHIBA and FBM that have not been designed for this purpose introduce large problem of instability.

The SECHIBA was modified to include parameterization of photosynthesis and a new parameterization of stomatal conductance that takes into account the effect of atmospheric $\mathrm{CO}_{2}$ on stomatal conductance. Validation with ground measurements gives satisfying results. Simulation with a doubled atmospheric $\mathrm{CO}_{2}$ shows little effect on transpiration when $\mathrm{CO}_{2}$ fertilization effect is important. But if this effect is limited for instance by nitrogen limitation, the decrease of transpiration becomes important.
\end{abstract}

\section{Carbon cycle, Hydrology, Terrestrial biosphere models}

\section{Couplage du cycle de l'eau et du carbone dans la biosphère}

RÉSUMÉ - Le couplage entre cycle de carbone et cycle de l'eau dans la biosphère terrestre est très important pour comprendre son rôle dans le cycle du carbone et sur le système climatique. Cet article présente un tel couplage entre un schéma de surface (SECHIBA) et une paramétrisation de processus biogéochimiques (comme par exemple la photosynthèse). Deux approches sont proposées: (1) coupler SECHIBA avec un modèle existant (FBM) et (2) construire un nouveau modèle biogéochimique sur la base de SECHIBA. Cette deuxième approche semble plus prometteuse. En effet, le couplage entre deux modèles (SECHIBA et FBM) qui n'ont pas été conçus dans cette optique pose de gros problèmes d'instabilité.

SECHIBA a été modifié pour inclure une paramétrisation de la photosynthèse et de la conductance stomatique qui prenne en compte l'effet du $\mathrm{CO}_{2}$ atmosphérique sur cette dernière. La comparaison à des mesures de terrain donne des résultats satisfaisants. Une simulation en doublement de $\mathrm{CO}_{2}$ montre une influence faible sur le flux de transpiration lorsque l'effet de fertilisation est total. En revanche, la limitation de la transpiration devient nettement plus importante si l'on suppose que l'effet de fertilisation est limité par un manque d'azote par exemple.

$$
\text { Cycle du carbone, Hydrologie, Modèle de fonctionnement de la biosphère terrestre }
$$

\section{INTRODUCTION}

During the last decade, biosphere models have been developed in two different ways:

1. To study interactions between vegetation and atmosphere or to be used as boundary conditions for atmospheric general circulation models (AGCM), Soil Vegetation Atmosphere Transfer has been developed. Such models give a good description of physical processes such as the energetic or hydrological budget. However biological processes such as LAI development are prescribed or crudely modeled.

\footnotetext{
' LMCE, Laboratoire de Modélisation du Climat et de l'Environnement, Commissariat à l'Energie Atomique, CE saclay, Bât. 709, Orme des Merisiers, 91191 Gif-sur-Yvette Cedex, France.
} 
2. On the other hand, biogeochemical models were developed to understand and describe the carbon cycle in the biosphere. With theses models, biological processes are well represented but the water cycle is represented in a simplified way.

A new trend is to couple these two kind of models. Since water and carbon cycles are highly coupled.

In this paper we present a coupled SVAT model: SECHIBA used as land surface scheme of the LMD ACGM and biogeochemical process. To this end a two-step approach is proposed:

1. To evaluate the feasibility of a coupling between two existing models: SECHIBA, the land surface scheme developed by DUCOUDRE et al. (1993), and the Frankfurt Biosphere Model (FBM, JANACEK et al., 1989). SECHIBA includes detailed parameterizations of the hydrological exchanges that occur at the biosphere / atmosphere interface, but has a rather crude representation of phenology. On the contrary, FBM has a complex description of the carbon cycle but a simplified calculation of hydrology. Our aim is to couple the two models, in collaboration with IPTC in Frankfurt, to improve both the simulation of water and carbon budgets.

2. To improve SECHIBA by including a mechanistically based parameterization of stomatal resistance that allows for exchanges of both carbon and water.

The two approaches are parallel.

\section{I - COUPLING SECHIBA TO FBM}

\section{Brief description of the models}

SECHIBA is the French acronym for "Schématisation des Echanges Hydriques à l'Interface BiosphèreAtmosphère ". It is a land-surface model that was developed for use within AGCMs. It calculates the fluxes of water, momentum and heat exchanged within the soil-plant-atmosphere continuum, as well as the water status of both soil and canopy and the temperature of the land-surface. Six climatic variables are required to force the model: surface air temperature $\left(T_{a}\right)$, water vapor concentration deficit of the ambient air, incident short-wave $\left(R_{g}\right)$ and long-wave radiations $\left(R_{l w}\right)$ reaching the land, surface wind speed $(\bar{W})$ and incident rainfall $(P r)$. The timestep of the model can vary, depending on the sampling of the forcing, from a few minutes to a few hours.

FBM is a global process oriented model that calculates the seasonal patterns of uptake and release of $\mathrm{CO}_{2}$ by vegetation and soil, and the resultant biomass and carbon budgets in both media. It is forced by $T_{a}, R_{g}, \operatorname{Pr}$ and soil moisture (SM). Because there is no global climatology of SM, FBM calculates, off-line, an annual cycle of daily soil moisture using a simplified model of hydrology forced by the given incident rainfall. For each biome represented in FBM some parameters were calibrated against mean ecological estimates of biomass, Net Primary Production (NPP) and annual respiration. The model runs with an hourly time-step but produces daily outputs. For a given climate FBM is run until an equilibrium is reached between NPP and litter production, within a given error bar.

\section{Description of the coupling}

A bidirectional pipe was then developed to allow the exchange of two variables between the models:

1. The Leaf Area Index (LAI) is calculated in FBM and is passed to SECHIBA through the pipe. In the standard version of SECHIBA, LAI is calculated using an empirical function of temperature, limited by prescribed minimum and maximum values. This variable is used for the calculation of canopy resistance, evapotranspiration and interception of rainfall by the foliage. 
2. The soil water content is calculated in SECHIBA and the pipe transmits it to FBM. Soil moisture is used in FBM to modulate the rate of photosynthetic activity. This is a rather major change for this model since, in its standard version, soil moisture is calculated off-line and once for all, that is it remains the same no matter how many iterations are needed for the model to reach its equilibrium. SM now varies from one integration to the other and, as will be discussed in the next subsection, this has some implications on the convergence criteria.

Both modcls are run with an hourly time step but LAI and SM are only exchanged daily, their variations being relatively slow with respect to the hour. Figure 1 displays the principle of this coupling.

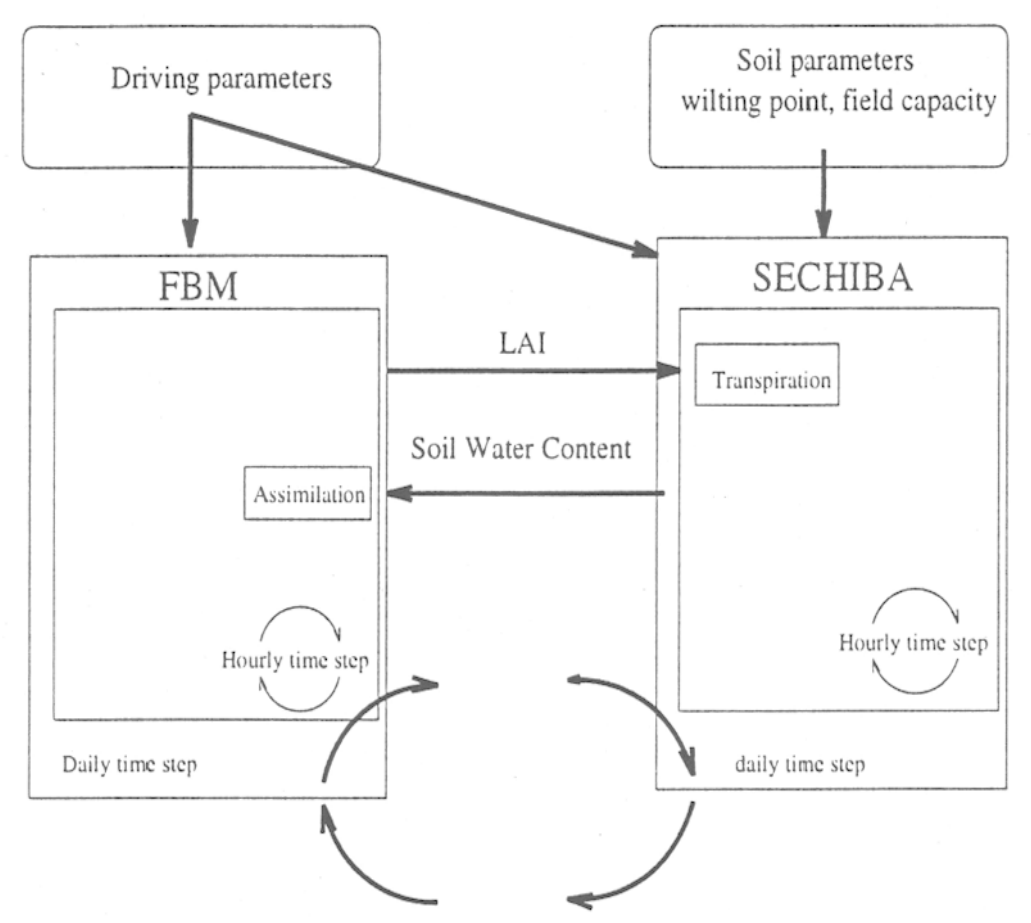

Fig. 1- Principle of the SECHIBA-FBM coupling. Principe du couplage SECHIBA-FBM.

\section{Preliminary results and comments}

As a first test of this coupled model, we have chosen to concentrate ourselves on a specific site located in Germany and covered with temperate deciduous forest. Figure 2 displays the LAI and the soil water content simulated respectively by SECHIBA, FBM and the coupled model. The forcing climate is derived from the Atlas of SHEA (1986), and the time evolution of both incident rainfall and ambient air temperature is displayed on figure 3 .

If we focus on the uncoupled models their major difference resides in: (1) the extreme values of the simulated leaf area index, and (2) the timing of the shooting and shedding phases.

In SECHIBA, the winter LAI value is about 2.5, while it is 0 in FBM. The minimum LAI value is prescribed to 1 in the former model for this particular biome, but the 2.5 value simulated points out that the relationship that has been chosen to link phenology to soil temperature in the root zone is certainly not appropriate. At winter time, such a deciduous forest has no more leaves! It is interesting to note though that the amplitude of the seasonal cycle of LAI is similar in both models. Regarding the timing of both the growing and the decay season, again the results simulated by SECHIBA look less realistic than the ones obtained with FBM. Moreover SECHIBA seems to regrow a few leaves in December, feature that is certainly not right. The total soil moisture computed looks quite similar in both models but we may note an earlier and more pronounced summer drying in 
SECHIBA than in FBM, as well as a more rapid refill of the soil in autumn in the former. But for the two models, soil moisture depletion in summer seems rather drastic and early in season.

Soil moisture simulated by the coupled model does not vary much from the one calculated in SECHIBA, except that summer drying occurs a few days earlier. We would need some data to see whether this change is or not an improvement. On the other hand changes in the seasonal evolution of LAI are quite large. The maximum value of LAI decreases from 4 in FBM to 3 in the coupled model and we note a 20-day shift of the whole cycle (shooting and shedding phases). We are embarrassed at this point to say whether all these changes have improved the simulation or not, due to the lack of surface data. We will continue running the coupled model over some other locations, with different land-surface cover.
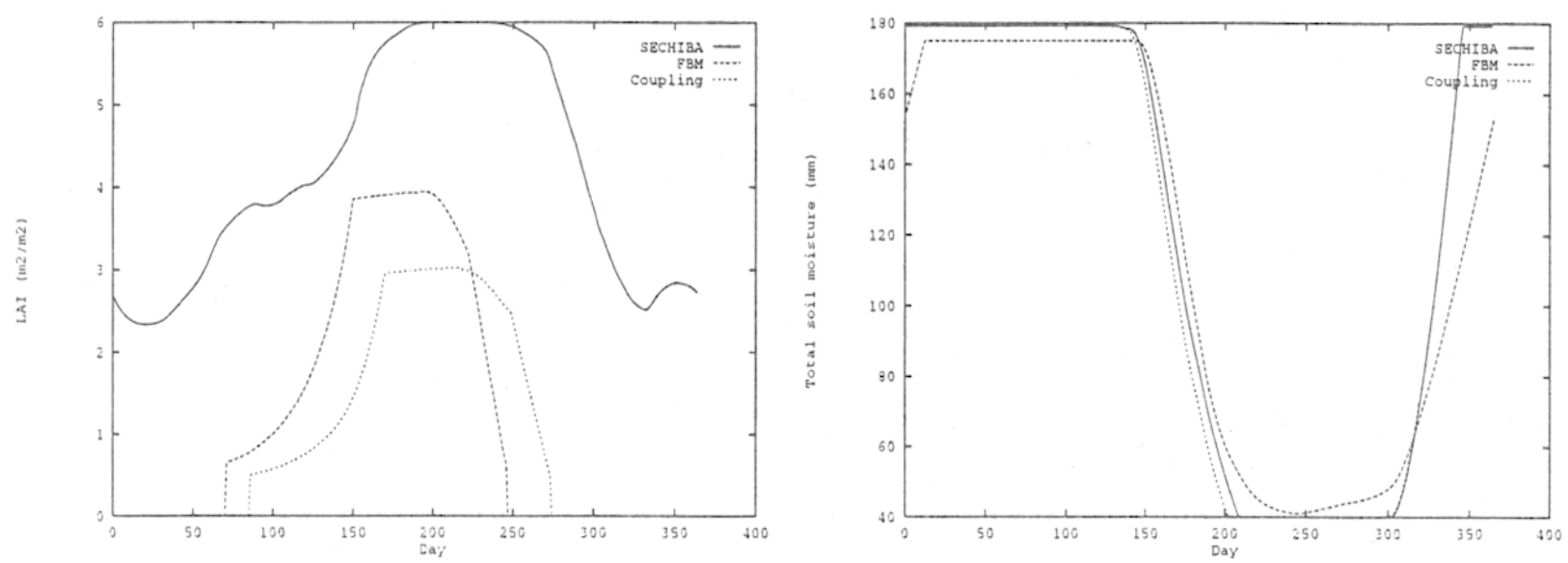

Fig. 2- LAI and soil water content simulated by SECHIBA, FBM and by the coupled SECHIBAVFBM model on a deciduous forest. LAI et contenu en eau du sol simulés par SECHIBA, le FBM et par le modèle couplé dans la cas d'une forêt caducifoliée.
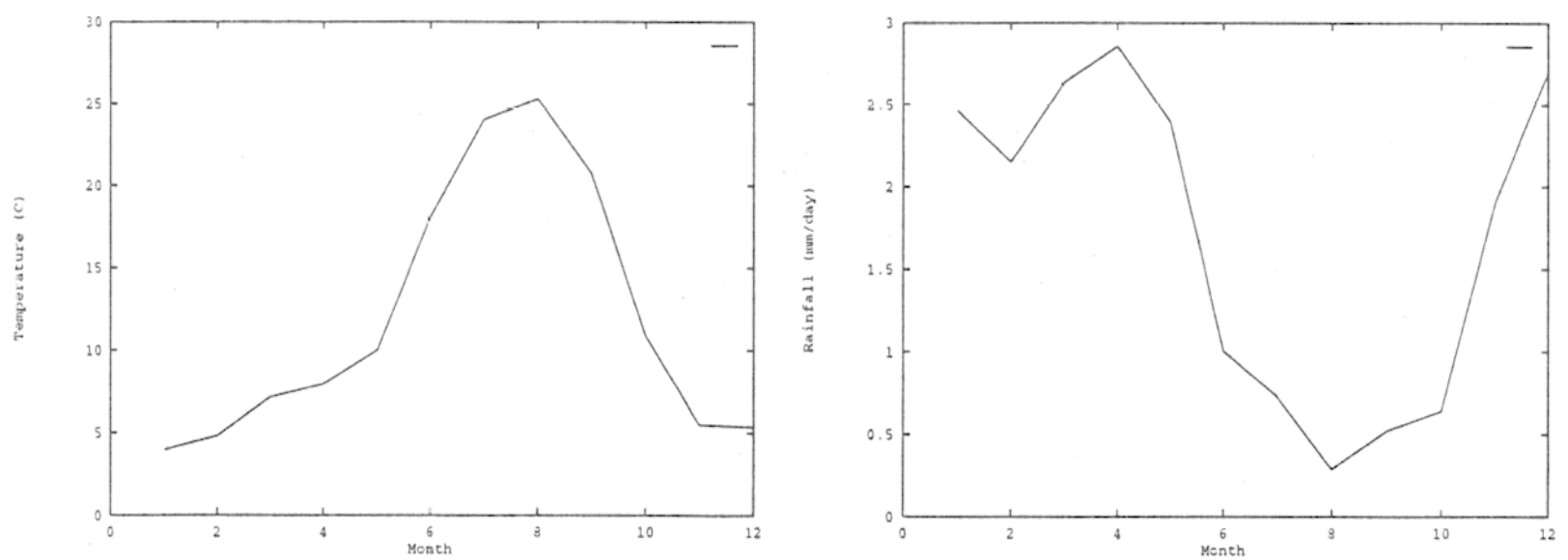

Fig. 3- Air temperature and rainfall from climatology for the deciduous forest site. Température de l'air et pluviométrie sur le site de forêt.

To achieve the convergence of the coupled model though, we had to strongly enhance the critical value of the difference between annual NPP and litter production (i.e. the convergence criteria). As a matter of fact, when the initial value of $0.006\left(\mathrm{~kg} \mathrm{C} \mathrm{m}^{-2}\right)$ is kept, the only solution the model can find is to put vegetation to death. We had to give a value of 0.08 to this threshold (i.e. more than 13 times the value needed in FBM) for the model to 
converge to the solution discussed above. These preliminary results have proved the feasibility of such coupling. Moreover it seems relatively difficult to extend this approach. Hence first there is not a direct coupling of cycles at stomata level which is the main process where coupling takes place, second because models are not designed to be coupled each others, The soil water calculated by SECHIBA introduce large instability in the FBM.

\section{II - SECHIBA-BGC: A COUPLED SVAT-BGC MODEL}

Up to now most land-surface models that have been implemented within atmospheric general circulation models (AGCMs) did not account for the exchanges of $\mathrm{CO}_{2}$ between the biosphere and the atmosphere. Yet this problem is of importance because a change in atmospheric $\mathrm{CO}_{2}$ can induce changes in vegetation functioning with direct effect on hydrology and Albedo, and consequently on climate. Vice versa, changes in soil water status can strongly influence vegetation production (WAELBROECK, 1993). The international community has now realized the importance of coupling the hydrological and the carbon cycles and gave rise to the Regional Interactions of Climate and Ecosystems (RICE) IGBP/GAIM project.

Following this trend, we have decided to improve SECHIBA. Because stomata is the place where exchanges of both $\mathrm{CO}_{2}$ and water vapor take place, we have chosen to replace the original parameterization of stomatal resistance, that is a function of incident solar radiation, water vapor concentration deficit of the ambient air and leaf area index (LAI), by a more sophisticated function based on the models developed by FARQUHAR et al. (1980) and BALL et al. (1987) (hereafter respectively FCS and BWB). FCS is a mechanistic model of photosynthesis for $\mathrm{C}_{3}$ plants based on enzymes kinetics and electron transport properties. BWB is a semi-empirical model of stomatal conductance in response to humidity, $\mathrm{CO}_{2}$ concentration and assimilation. Such models based on biochemical processes are very interesting because they allow for the study of the complex interactions between assimilation and transpiration. Recently SELLERS et al. (1992a) have used this approach to improve the $\mathrm{SiB}$ model.

\section{The original parameterization of stomatal resistance}

In the standard version of SECHIBA, canopy resistance is calculated using an empirical formulation derived by LOHAMMAR et al. (1980) from JARVIS (1976):

$$
r_{c}=\frac{l}{L A I} \frac{I_{0}+I_{h s}}{I_{0}} \frac{a+\lambda \delta_{c}}{k_{0}}
$$

$\delta_{c}=$ water vapor concentration deficit of the ambient air $\left(\mathrm{kg} \mathrm{m}^{-3}\right)$

$I_{0}=$ incoming solar radiation

$I_{h s}=$ half light saturation factor $\left(125 \mathrm{~W} \mathrm{~m}^{-2}\right)$

$a, k_{0}, \lambda=$ constants that link $\delta_{c}$ to $r_{c}$

Even though the stomata aperture is not modulated by soil water, this variable influences canopy transpiration through the use of the so-called « surface relative humidity $h_{g}$ » entering the calculation of the gradient of specific humidity between the land-surface and the overlying air $\left(\Delta q_{t r}\right)$.

An architectural resistance $r_{0}$ is added to $r_{c}$ to account for (1) the attenuation of light and wind within the foliage, and (2) the gradient of specific humidity between the lower and the upper leaves. This additional resistance is an improvement to the « Big Leaf » approximation that is made in SECHIBA.

But this approach suffers from a number of shortcomings:

1. Stomatal conductance does not depend on $\mathrm{CO}_{2}$, nor on temperature or nutrients availability, yet we know that those variables are not negligible. 
2. As a consequence of the "Big Leaf " approximation, vegetation has no vertical dimension and the correction factor $\left(r_{0}\right)$ is unable to reproduce with enough accuracy the effect of light attenuation within the canopy and of plant's resources optimization (e.g. nitrogen).

\section{The new formulation of stomatal conductance}

\section{a) At the leaf level}

BALL et al. (1987) have derived an empirical expression for stomatal conductance $g_{s}\left(\mathrm{~mol} \cdot \mathrm{m}^{-2} \cdot \mathrm{s}^{-1}\right)$ as a function of assimilation $A\left(\mu \mathrm{mol} \cdot \mathrm{m}^{-2} \cdot \mathrm{s}^{-1}\right)$, atmospheric $\mathrm{CO}_{2}$ concentration $C_{u}(\mathrm{ppm})$ and relative humidity $h_{r}(\%)$ of the ambient air:

$$
g_{s}=m A \frac{h_{r}}{C_{a}}+b
$$

$m$ and $b$ are derived from laboratory measurements using $C_{3}$ species.

Photosynthesis is calculated from FARQUHAR et al. (1980):

$$
A=V_{c}\left(l-\Gamma * / C_{i}\right)-R_{d}
$$

$V_{c}\left(\mu \mathrm{mol} . \mathrm{m}^{-2} \cdot \mathrm{s}^{-1}\right)$ is the rate of carboxylation, $\Gamma_{*}(\mathrm{ppm})$ the $\mathrm{CO}_{2}$ compensation point in absence of non-photorespiratory respiration, $R_{d}\left(\mu \mathrm{mol} . \mathrm{m}^{-2} . \mathrm{s}^{-1}\right)$ the rate of non-photorespiratory respiration and $C_{i}$ the $\mathrm{CO}_{2}$ concentration at the carboxylation site.

The rate of carboxylation is expressed as the more limiting factor of Rubisco activity, $W_{c}$, and RuBP regeneration, $W_{j}\left(\mu \mathrm{mol} . \mathrm{m}^{-2} \cdot \mathrm{s}^{-1}\right)$ :

$$
V_{c}=\min \left(W_{c}, W_{j}\right)
$$

The Rubisco-limited rate is given by:

$$
W_{c}=\frac{V_{c m a x} C_{i}}{C_{i}+K_{c}\left(1+O_{i} / K_{O}\right)}
$$

$V_{\text {cmax }}\left(\mu \mathrm{mol} \cdot \mathrm{m}^{-2} \cdot \mathrm{s}^{-1}\right)$ is the maximum rate of RuBP carboxylation, $K_{C}$ and $K_{O}$ are the Michaelis-Menten constants for enzyme catalytic activity for $\mathrm{CO}_{2}$ and $\mathrm{O}_{2}$ respectively, and $O_{i}$ is the intercellular concentration of oxygen.

The RuBP-regeneration-limited rate is defined by:

$$
W_{j}=\frac{V_{j}}{1+2 \Gamma * / C_{i}}
$$

$V_{j}$ is the potential rate of RuBP regeneration. It depends on the incident photon flux $Q . V_{j}$ can be empirically described using a non-rectangular hyperbola:

$$
\left.V_{j}=\frac{1}{2 \Theta}\left[\alpha_{j} Q+V_{j \max }-\sqrt{\alpha_{j} Q+V_{j \max }}\right)^{2}-4 \Theta \alpha_{j} Q V_{j \max }\right]
$$

$\alpha_{j}$ is the quantum yield of RuBP regeneration, $V_{\text {jmax }}$ the maximum potential rate of RuBP regeneration at quantum-saturation and $\Theta$ the curvature of the quantum response. Equation (2) gives the stomatal conductance $g_{s}$ as a function of assimilation $A$. Equation (3) gives $A$ as a function of $C_{i}$. A third equation can be expressed that relates assimilation and stomatal conductance to the gradient of $\mathrm{CO}_{2}$ between the atmosphere and the carboxylation site:

$$
A=g_{s}\left(C_{u}-C_{i}\right) / 1.6
$$

The value of 1.6 represents the ratio of water vapor diffusivity to the diffusivity of $\mathrm{CO}_{2}$. 
The system formed by equations $2,3,8$ is solved using a simple iterative method that converges very rapidly in most cases.

\section{The effect water stress}

There have been so far very few studies of the effect of water stress on stomatal aperture. But it is well known that if soil moisture decreases, stomatal resistance will increase because of the subsequent decrease of leaf water potential or of chemical mediators such as abscisic acid (WLLMER, 1988; ZHANG and DAVIES, 1989). When the water stress becomes important it can also affect directly photosynthesis (FARQUHAR and SHARKEY, 1982). In the model, we will not consider the problem of chemical mediators. A moisture stress factor $\gamma_{w}$ (comprised between 0 and 1 ) is introduced in equation (2):

$$
g_{s}=m A \gamma_{w} \frac{h_{s}}{C_{a}}+b
$$

$\gamma_{w}$ is defined after McMURTRE et al. (1960):

$$
\gamma_{w}= \begin{cases}1 & \text { if } f_{w}>f_{w 1} \\ 1-\frac{f_{w}-f_{w 0}}{f_{w 1}-f_{w 0}} & \text { if } f_{w 0}<f_{w}<f_{w !} \\ \text { if } f_{w}<f_{w 0}\end{cases}
$$

$f_{w}$ is the water fraction available for the plant in the root zone; $f_{w 0}=0.028$ and $f_{w 1}=0.5$ are the soil water fractions inducing respectively closure and maximum opening of the stomata.

\section{b) At the canopy level}

Calculation of the equivalent stomatal conductance at the canopy level, $g_{c}\left(g_{c}=1 / r_{c}\right)$, requires the integration of $g_{s}$ over the depth of the canopy, that is over the leaf area index (LAI):

$$
g_{c}=\int_{0}^{L A l} g_{s}(l) d l
$$

Similarly we can integrate the assimilation rate $\left(A_{c}=\int_{0}^{L A I} A(l) d l\right)$.

And, for the sake of simplification, we assume there is no gradient of humidity nor of $\mathrm{CO}_{2}$ within the canopy. $\mathrm{A}(\mathrm{l})$ is expressed, through $V_{\text {cmar }}$ and $V_{\text {jmar }}$ following the Beer's law of attenuation, as for light within the canopy (MONSI and SAEKI, 1953; FIELD, 1983; FIELD and MOONEY, 1986; FARQUHAR, 1989; SELLERS et al., 1992a).

$$
V_{\text {cmax }}(l)=V_{c \max }^{0} e^{-k l}, V_{\text {jmax }}(l)=V_{\text {jmax }}^{0} e^{-k l}
$$

$l$ is the cumulated LAI and $k$ the attenuation coefficient.

\section{Validation for a tropical forest site (ARME site) and a $\mathrm{C}_{4}$ grassland (FIFE)}

To validate SECHIBA-BGC we have used two sets of data obtained from two regional experiments: ARME (SHUTTLEWORTH, 1988; SHUTTLEWORTH et al., 1984a) in 1984 on a tropical evergreen forest and FIFE (SELLERS et al., 1988; SELLERS et al., 1992b; SELLERS and HALL, 1992) in 1987-1989 on a C $_{4}$ grassland. These two sites represent very different ecosystems, which is very interesting for several reasons:

-It will validate both the parameterization of $\mathrm{C}_{3}$ and $\mathrm{C}_{4}$ models of photosynthesis.

-Tropical forest has a high LAI. It will then be a good way to test the parameterization of light and photosynthetic rate decrease into the canopy. 
- The $\mathrm{C}_{4}$ grassland on the other hand has a great limitation of water which will allow testing of water stress parameterization.

a) Validation on the tropical forest site

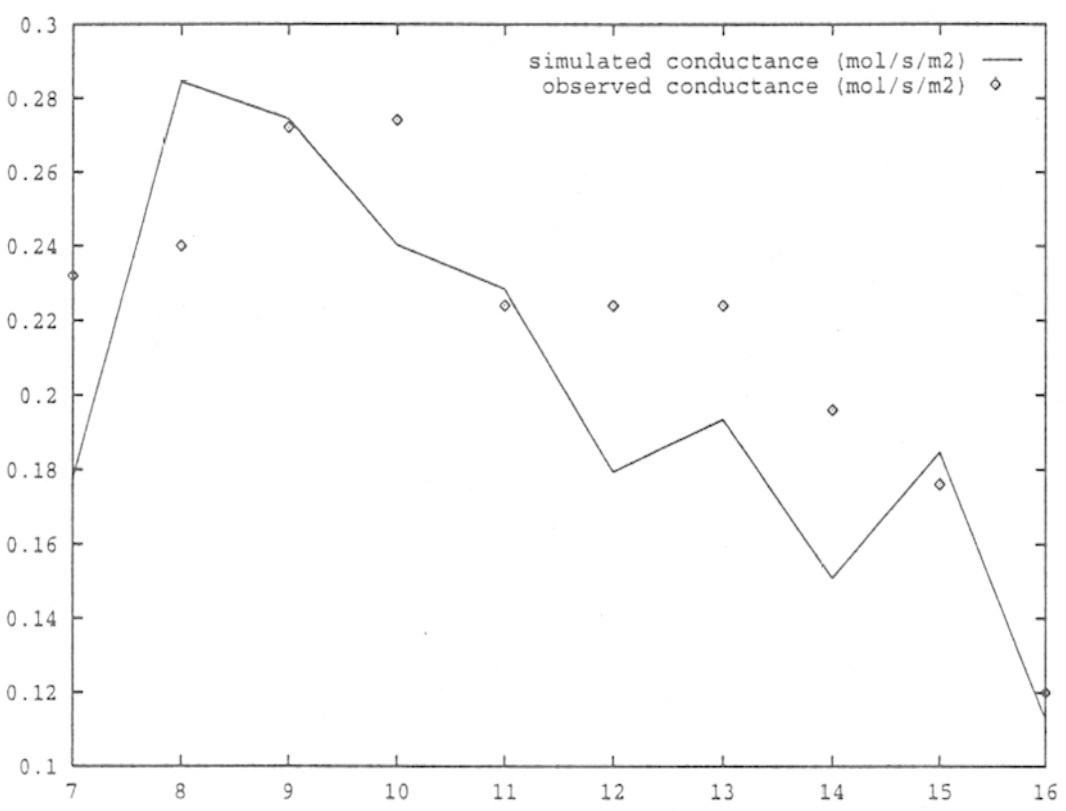

Fig. 4- Simulated and observed daily stomatal conductance course at the top of the canopy at Ducke. Cycle diurne de la conductance stomatique au sommet de la canopée sur le site de Ducke.

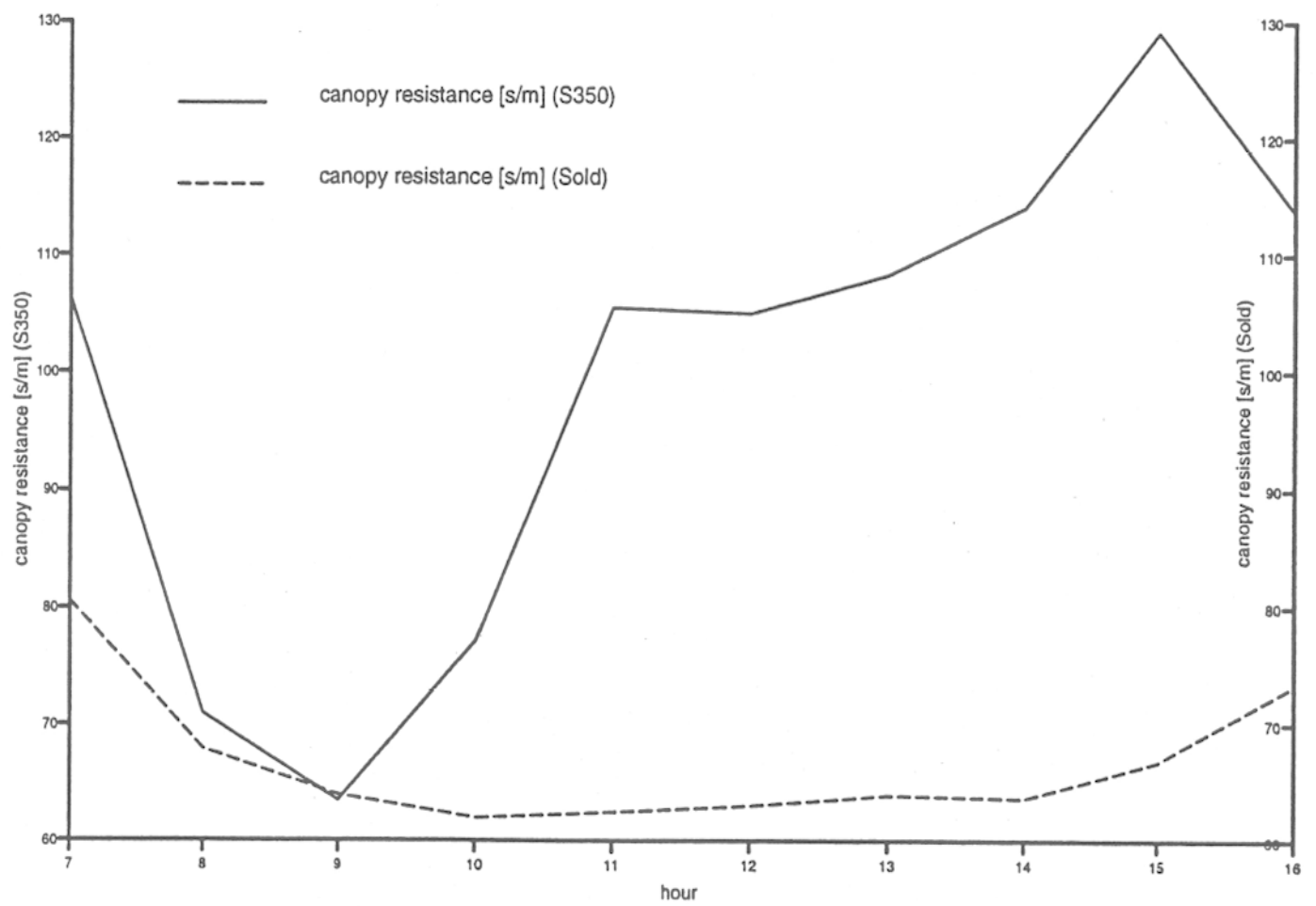

Fig. 5- Simulated daily stomatal resistance with the old and new parameterization at Ducke. Conductance stomatique journalière simulée avec l'ancienne et la nouvelle paramétrisation à Ducke. 
The canopy (or equivalent stomatal) resistance simulated by SECHIBA-BGC (hereafter S350) agrees well with the field measurements of SHUTTLEWORTH et al. (1984b) and DOLMAN et al. (1991). In particular we simulate correctly the decrease of conductance into the canopy. The daily mean stomatal resistance simulated by both SECHIBA (hereafter sold) and SECHIBA-BGC are very similar but the daily course is very different. In S350 there is an important diurnal variation as it was observed by ROBERTS et al. (1990) (fig. 4), while in sold there is very little variation of $r_{c}$ throughout the day (fig. 5).

For the grassland site simulation of SECHIBA-BGC both latent heat flux and assimilation agree well with measurements (fig. 6, 7).

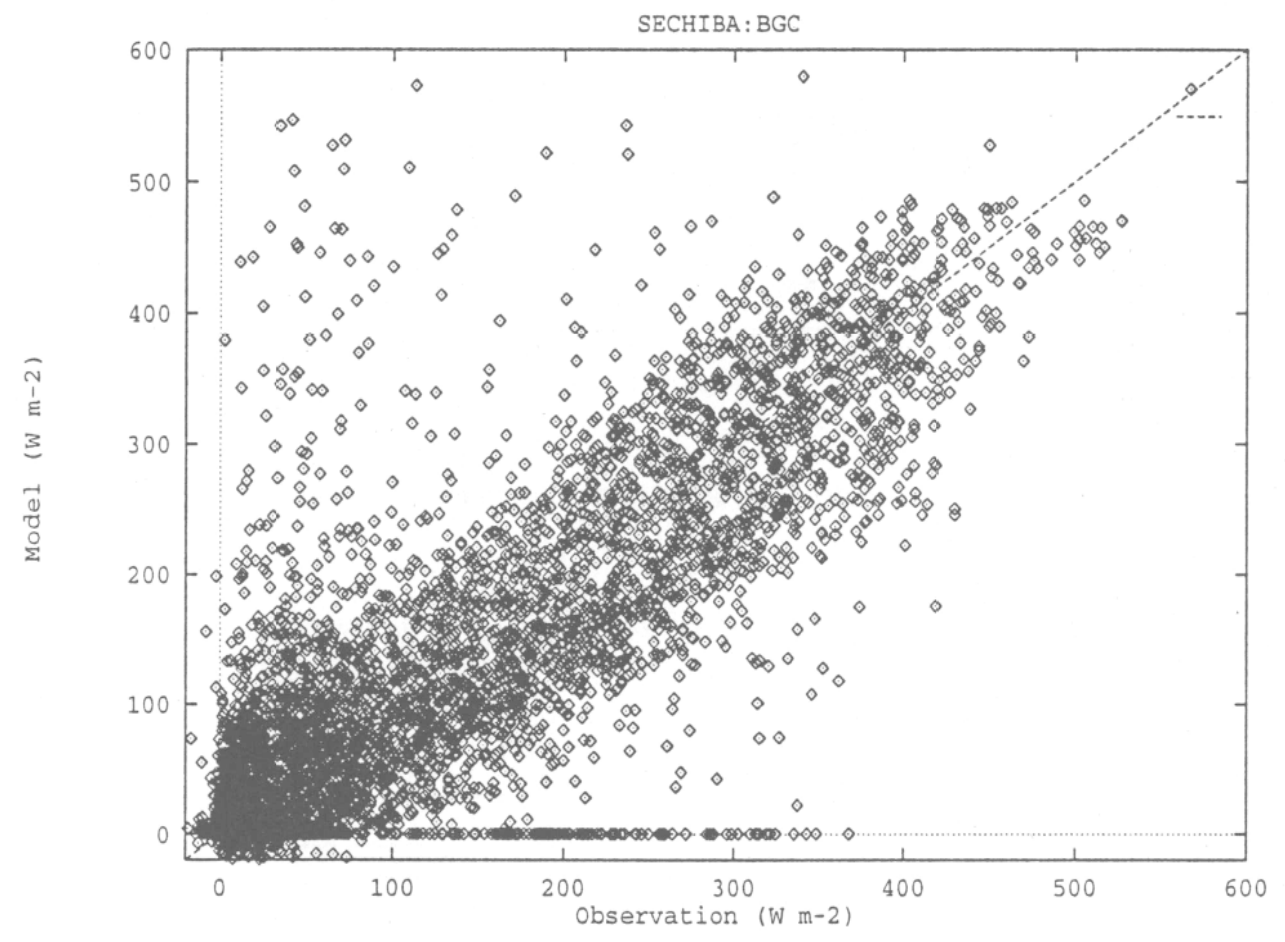

Fig. 6. Simulated vs observed hourly evapotranspiration for FIFE. Comparaison modèle/mesure de l'évapotranspiration pour FIFE.

\section{b) Doubled $\mathrm{CO}_{2}$ experiments}

Since this new version of SECHIBA was developed to allow for some scenarios of climate change, we have carried out a doubled $\mathrm{CO}_{2}$ experiment. In the first one (hereafter S700) we assume there is no limitation to the $\mathrm{CO}_{2}$ fertilization effect. In the second one (hereafter $5700 \mathrm{Nlim}$ ) we introduce an indirect limitation by halving the ratio of carboxylation to regeneration. This simulates the limitation that can be caused by a deficit in soil nitrogen (MCMURTRIE et al., 1990).

The table displays some annual results obtained for two different types of land-surface: the tropical evergreen forest site already presented in the previous subsection, and a grassland site located in the Netherlands for which the climatic data were provided within the framework of PILPS (Project of Intercomparison of Land-surface Parameterization Schemes). 


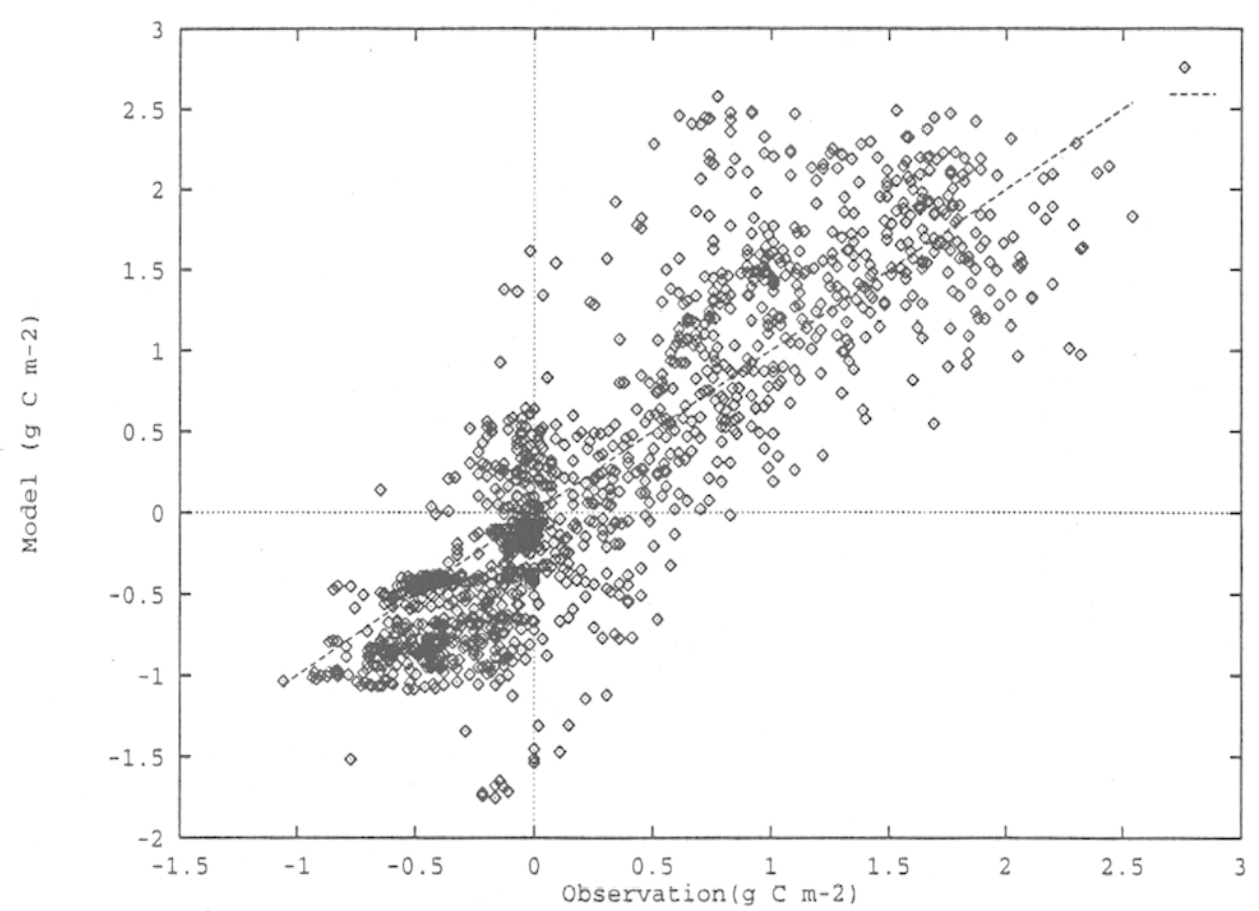

Fig. 7- Simulated vs observed net $\mathrm{CO}_{2}$ fluxes. Comparaison modèle/mesure du flux net de $\mathrm{CO}_{2}$.

Table - Annual changes in the simulated GPP and ETR when doubling $\mathrm{CO}_{2}$ with and without fertilization effect. Changement de la production primaire brute et de l'évapotranspiration en cas de doublement de $\mathrm{CO}_{2}$ avec ou sans limitation de l'effet de fertilisation.

\begin{tabular}{|lll|}
\hline Simulations & Tropical forest & Grassland \\
\hline \multicolumn{3}{|c|}{ 1. Increase of GPP } \\
\hline S700 - S350 & $+61 \%$ & $+44 \%$ \\
S700Nlim - S350 & $+9 \%$ & $+8 \%$ \\
S700Nlim - S700 & $+49 \%$ & $+19 \%$ \\
\hline \multicolumn{3}{|c|}{2. Decrease of ETR } \\
\hline S700 - S350 & $-6 \%$ & $-7 \%$ \\
S700Nlim - S350 & $-22 \%$ & $-7 \%$ \\
S700Nlim - S700 & $-17 \%$ & $-2 \%$ \\
\hline
\end{tabular}

\section{Tropical forest}

Doubling $\mathrm{CO}_{2}$ with no limitation of its fertilization effect results in an increased annual photosynthetic activity of about $61 \%$, and a consequent decrease of stomatal conductance $(22.5 \%)$. The resulting transpiration rate is also lower in $\$ 700$ than in $\$ 350(-11 \%)$. When a limitation effect due to nitrogen is introduced, stomatal resistance increases much more (+61\% in S700Nlim when compared to S350), inducing a larger decrease in the rate of transpiration $(-38 \%)$ but an almost unchanged gross primary production $(+9 \%)$. $\mathrm{CO}_{2}$ fertilization effect can therefore be very strongly cut off by the impoverishment of soils.

In both runs total evapotranspiration, calculated as the sum of transpiration, interception loss and evaporation of soil water, decreases less than transpiration alone. This is because, as plants extract less water from the soil, the soil resistance to evaporation decreases, surface relative humidity increases and so does the evaporation of 
soil water. The partitioning of evapotranspiration between canopy and soil therefore changes: in S350 transpiration represents $75 \%$ of the total water flux whereas in S700Nlim it accounts for only $50 \%$.

\section{Grassland}

The total annual evapotranspiration (ETR) does not change much for this grassland site, contrary to what we obtaincd for tropical evergreen forest. However the seasonal evolution of ETR is very different (fig. 8) from one simulation to the other. In S700 and S700Nlim, ETR is reduced in Spring and Autumn, enlarged in summer when compared to $\mathrm{S} 350$. The seasonal contrast is then reduced when $\mathrm{CO}_{2}$ is doubled.

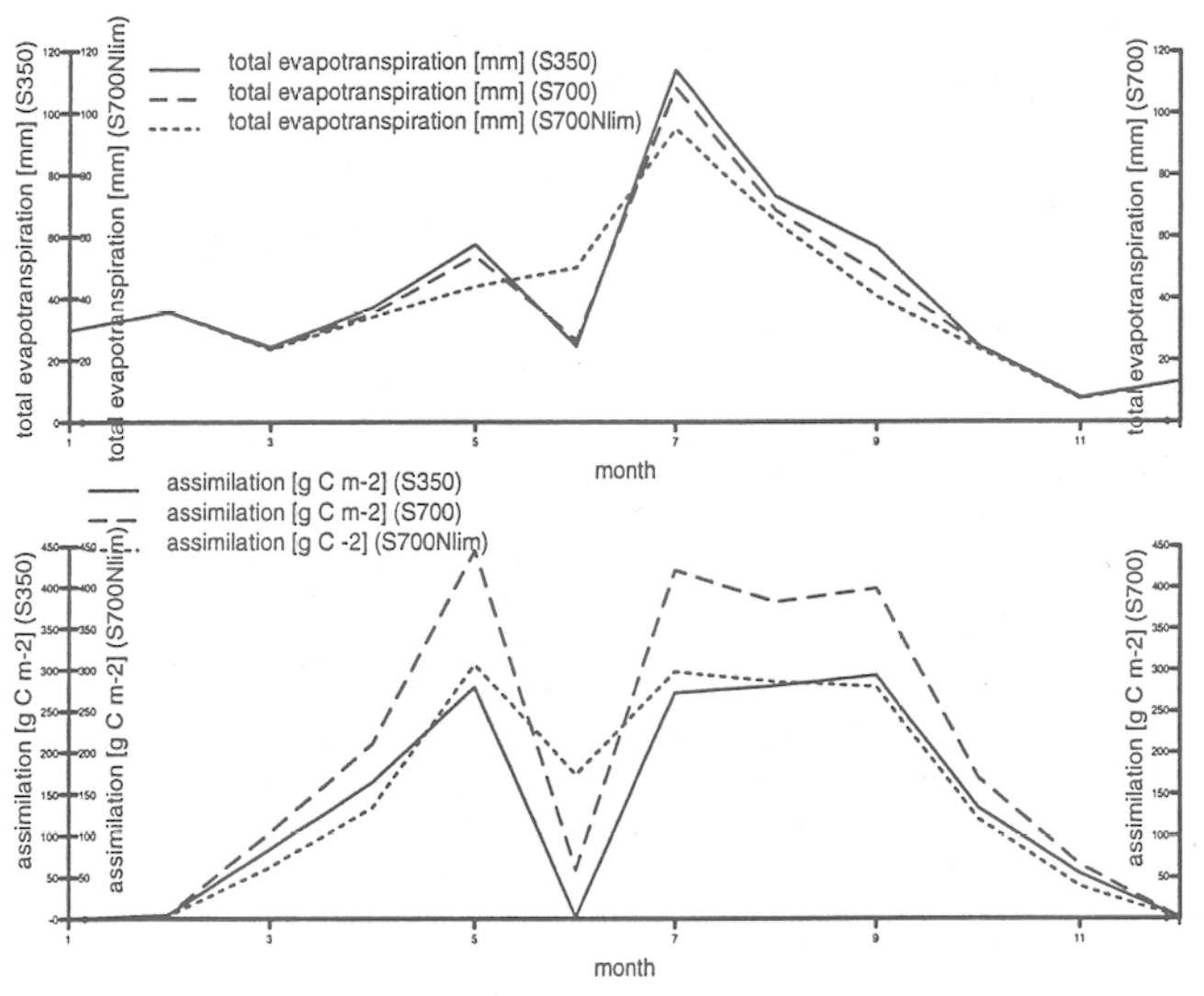

Fig. 8- Monthly mean of ETR and assimilation over grassland for S350, S700 and S700Nlim. Moyennes mensuelles de lETR et de l'assimilation sur la prairie pour S350 S700 et S700Nlim.

\section{SUMMARY AND CONCLUSION}

The coupling between SECHIBA and FBM seems to be difficult to achieve since models have been designed separately and great problems of stability of the two models occurred.

The second approach which consists in developing the biogeochemical model directly from SECHIBA appears to be more promising. In SECHIBA-BGC: 
-We now consider both exchanges of water vapor and $\mathrm{CO}_{2}$. Furthermore the stomatal conductance depends directly on assimilation and thus it varies not only with light but also with all factors influencing photosynthesis (e.g. nutrients, temperature, water stress).

- Stomatal conductance is explicitly integrated over the depth of the canopy and we can avoid the use of artificial parameters such as the architectural resistance that is used in the standard version of SECHIBA.

-Two more variables are now simulated and can be compared to available measurements: the gross primary production and the intercellular $\mathrm{CO}_{2}$ concentration.

The improvements brought by this new parameterization of stomatal conductance $\left(g_{c}\right)$ appear clearly in the simulation carried on for the tropical evergreen forest and grassland site. Both the seasonal and the diurnal cycles of $g_{c}$ agree with the measurements. It should be noted that the parameters of BALL and FARQHUAR have been calibrated independently.

When $\mathrm{CO}_{2}$ is doubled, and there is no limitation of its fertilization effect, changes in evapotranspiration are small because the photosynthetic activity has not yet reached its saturation value, and the stomata stay quite opened. When we prescribe a limitation of the $\mathrm{CO}_{2}$ fertilization effect by some nutrients such as nitrogen, the stomatal closure becomes important. In this case, we get a sensible decrease in plant transpiration. Changes in the hydrological cycle are quite different from one vegetation type to the other. For the tropical evergreen forest we get a relatively constant decrease of ETR throughout the year, while for grassland the seasonal variation of ETR is modified but not so much its annual value.

We must note that there is no feedback to the atmosphere, that is the changes we simulate do not affect the climate variables that are prescribed to their present-day values in all simulations.

We expect that, if this model was implemented in a climate model, the decreased ETR in case of a doubling $\mathrm{CO}_{2}$ will reduce the relative humidity of the ambient air, and therefore induce a further closure of the stomata. We therefore imagine a positive feedback. Moreover we must say that some inconsistencies remain in the model regarding the time evolution of leaf area index: LAI is still calculated as in the standard version of SECHIBA, and there is therefore no link between assimilation and phenology which, obviously, has to be corrected.

Such study though demonstrates the impact of coupling both cycles of water vapor and carbon on the simulated surface hydrological cycle and points out to the necessity of improving the land surface schemes used within AGCMs. It also demonstrate that because of the complex interactions between the hydrologic and carbon cycle, the change in stomatal conductance with increasing atmospheric $\mathrm{CO}_{2}$ cannot be prescribed (for instance with a doubled stomatal resistance) and is strongly dependent of the ecosystem.

\section{REFERENCES}

BALL J., WOODROW I. \& BERRY J. (1987) - A model predicting stomatal conductance and its contribution to the control of photosynthesis under different environmental conditions. Progress in Photosynthesis, 4, p. 221224.

DOLMAN A., GASH J., ROBERTS J. \& SHUTTLEWORTH W. (1991) - Stomatal and surface conductance of tropical rainforest. Agric. Forest. Meteor., 54, p. 303-318.

Ducoudré N., LAVAl K. \& PerRIER A. (1993) - SECHIBA, a New Set of Parametrizations of the Hydrologic Exchangcs at the Land-Atmosphere Interface within the LMD Atmospheric General Circulation Model. J. Climate, 6, p. 248-273.

FARQUHAR G. (1989) - Models of integrated photosynthesis of cells and leaves. Phil. Trans. Roy. Lond., Ser. B, Biol. Sci., 323, p. 357-367.

FARQUHAR G. \& SHARKEY T. (1982) - Stomatal conductance and photosynthesis. Ann. Rev. Plant Physiol., 33, p. 317-345.

FARQUHAR G., VON CAEMMENER S. \& BERRY J. (1980) - A biochemical model of photosynthesis $\mathrm{CO}_{2}$ fixation in leaves of $\mathrm{C}_{3}$ species. Planta, 149, p. 78-90. 
FIELD C. (1983) - Allocation leaf nitrogen for the maximization of carbon gain: leaf age as a control on the allocation program. OEcologia, 56, p. 341-347.

FIELD C. \& MOONEY H. (1986) - The photosynthesis-nitrogen relationship in wild plants. In « On the economy of Plant Form and Function », GrvnisH T. (Ed.), Cambridge University Press, Cambridge, p. 25-55.

JANACEK A., BENDEROTH G., LÜDEKE M., KindeRMANN J. \& KoHLMAIER G. (1989) - Model of the seasonal and perennial carbon dynamics in deciduous-type forests controlled by climatic variables. Ecol. Mod., 49, p. 101-124.

JARVIS P. (1976) - The interpretation of the variations in leaf water potential and stomatal conductance found in canopies in the fields. Phil. Trans. Roy. Lond., Ser. B, 273, p. 593-610.

LOHAMMAR T., LARSSON S., LINDER S. \& FALKE S. (1980) - Simulation models of gazeous exchange in Scotch pine. Structure and function of Nothern Coniferous forest. Ecol. Bull., 32, p. 505-523.

MCMURTRIE R., ROOK D. \& KelliHeR F. (1990) - Modelling the yield of Pinus radiata on a site limited by water and nitrogen. For. Ecol. Manage., 30, p. 381-413.

MONSI M. \& SAEKI T. (1953) - Über den Lichtfactor in der Pflanzengesellschaften und seine Bedeutung für die Stoffproduktion. Jpn. J. Bot., 14, p. 22-52.

ROBERTS J., CABRAL O. \& DE AGUIAR L. (1990) - Stomatal and boundary-layer conductance measured in a terra firme rain forest, Manaus, Amazonas, Brazil. J. Appl. Ecol.

Sellers P., Berry J., Collatz G., Field C. \& Hall F. (1992a) - Canopy Reflectance, Photosynthesis, and Transpiration. III. A Reanalysis Using Improved leaf Models and a new Canopy Integration Scheme. Remote Sens. Environ., 42, p. 187-216.

Sellers P., Hall F., ASRaR G., STREhel D. \& MURPHY R. (1988) - The first ISLSCP Field Experiment (FIFE). Bull. Amer. Meteo. Soc., 69, p. 22-27.

SELlERS P. \& HALL F. (1992) - FIFE in 1992: Results, scientific gains and future research directions. J. Geophy's. Res., 97, (D17), p. 19,091-19,109.

Sellers P., Hall F., AsRar G., STRebel D. \& MURPhy R. (1992b) - An overview of the first international satellite land surface climatology project (ISLSCP) field experiment (FIFE). J. Geophys. Res., 97, (DI7), p. $18,345-18,372$.

SHUTTLEWORTH W. (1988) - Evaporation from amazonian rainforest. Proc. R. Soc. London, Ser. B, 233, p. 299334.

Shuttleworth W., Gash J., lloyd C., Moore C., Roberts J., Marques A., Fisch G., Silva V., Ribeiro M., Molion L., de Sa L., Nobre J., Cabral O., PaTel S. \& DE MORAes J. (1984a) - Observations of radiation exchange above and below Amazonian forest. Quart. J. Roy. Meteor. Soc., 110, p. 1143-1162.

Shuttleworth W., Gash J., lloyd C., Moore C., Roberts J., Marques A., Fisch G., Sllva V., Ribeiro M., Molion L., de Sa L., Nobre J., Cabral O., Patel S. \& de Moraes J. (1984b) - Eddy correlation measurements of energy partition for Amazonian forest. Quart. J. Roy. Meteor. Soc., 110 , p. 1143-1162.

WAELBROECK C. (1993) - Climate-soil processes in the presence of permafrost: a systems modelling approach. Ecol. Mod., 69, p. 185-225.

WLLMER C. (1988) - Stomatal sensing of Environnement. Bot. J. Linn. Soc., 34, p. 205-217.

ZHANG \& DAVIES (1989) - Sequential response of whole plant water relations to prolonged soil drying in the regulation of stomatal behaviour of sunflower plants. New Phytol., 113, p. 167-174. 